\title{
Humor, Contempt, and the Exemption from Sense
}

\begin{abstract}
Building on the theory of humor advanced by Yves Cusset in his recent book Rire: Tractatus philocomicus, I argue that we can understand the phenomenon in terms of what Jean-Luc Nancy, following Roland Barthes, has called the exemption from sense. I attempt to show how the humorous sensibility, understood in this way, is entirely incompatible with the experience of others as contemptible. I conclude by developing some of the normative implications of this, focusing specifically on the question whether it is ever morally permissible to treat others with contempt.
\end{abstract}

Keywords: humor, contempt, sense, ethics, Jean-Luc Nancy

According to the theory that has been predominant throughout the vast majority of the history of Western philosophical reflection, laughter is best understood as expressing the laugher's feeling of superiority over the target of her laughter. This view goes back at least to Aristotle's Poetics, where comedy is defined as "an imitation of men worse than the average," and more specifically of men who are ridiculous. ${ }^{1}$ A similar idea is taken up by the Roman rhetorician Quintilian, who suggests in his Institutio Oratoria that "laughter is never far removed from derision." Among early modern philosophers, Thomas Hobbes gives what is probably the most straightforward expression of the idea, arguing that "laughter is nothing else but a sudden glory arising from a sudden conception of some eminency in ourselves, by comparison with the infirmities of others, or with our own formerly." ${ }^{3}$ There are two points that different versions of this view, typically referred to in the contemporary literature as the Superiority Theory, have in common. First, they attempt to show how laughter presents the laughing subject to herself as distanced in a specifically practical sense from the target of laughter. Charles Baudelaire illustrates this point especially vividly: our laughter at others' misfortunesfor example, their slipping and falling on ice or their tripping at the edge of a pavementis most basically an expression of unconscious pride. What we are really thinking is 
something like “'I don't fall, I don't; I walk straight, I do; my footstep is steady and assured, mine is. You won't catch me being stupid enough not to see where the pavement ends, or that there is a pavingstone in my way." "“4 The distance established by the laugh, though, is not just the distance of a rank ordering; it is not merely the case that the laugher experiences herself as higher on some scale of value than the target of laughter. And this is the second point: the distance opened up in laughter establishes, or at least runs the risk of establishing, a relation of contempt. In laughing at other persons, we abandon what Stephen Darwall calls the second-person standpoint. We do not make ourselves answerable to them within relationships characterized by mutual respect; the targets are given rather within a distance of reflection, as objects rather than as genuine partners in dialogue. This point is emphasized by Hobbes and by Samuel Pufendorf, who both treat laughter directed at others as a sign of contempt and thus as incompatible with the kind of sociability that the natural law obligates us to promote. ${ }^{5}$

The Superiority Theory is no longer the most widely accepted account of laughter. Indeed the idea that laughter necessarily expresses feelings of superiority probably strikes many of us today as so plainly false that we wonder how it could have been accepted for so long as the correct account. Nonetheless, there is one element of the theory that I believe is importantly right: laughter can and often does distance us from others, suspending to some degree our participation in the intersubjective, practical world. And this distancing certainly can manifest itself in relations of contempt. What I want to argue in this paper, though, is that it can just as well give rise to a very different kind of ethical sensibility, one that is entirely incompatible with contempt. Following the argument that Yves Cusset advances in his recent book Rire: Tractatus philo-comicus, I 
will begin in what follows by emphasizing the way in which humor-in contrast, for example, to ridicule, sarcasm, and raillery — opens up a space of wonder where what becomes manifest is the simple fact of our being-with. Cusset suggests that this humorous sensibility should be understood as an epoché in the phenomenological sense, where the imperatives of the given, everyday practical world are put in suspense. I will argue, though, that this sensibility can be understood more adequately in terms of what Jean-Luc Nancy, following Roland Barthes, has called the exemption from sense. Next, I will show how the humorous sensibility, understood in terms of the exemption from sense, is incompatible with the experience of others as contemptible. I will conclude by developing some of the normative implications of this, focusing specifically on the question whether it is ever morally permissible to treat others with contempt.

\section{Laughter as Expression of Wonder: Devos contra Democritus}

In order to bring out the sensibility he thinks is proper to humor, Cusset contrasts the laughter of Democritus, accounts of which come down to us from the apocryphal letters of Hippocrates, with the laughter provoked by the twentieth-century French humorist Raymond Devos. Democritus, of course, was known in antiquity as "the laughing philosopher." His laughter, though, was not a source of joy for the citizens of his native Abdera, who saw in it a potential symptom of madness. The problem was not merely that Democritus liked to laugh, but rather that he seemed to laugh excessively and at things that were not funny. Concerned for the well being of their renowned native son, the Abderites appealed to Hippocrates, who they hoped would be able to discover the causes of his laughter. Asked explicitly why he laughed, Democritus insisted that it was because the conduct of the Abderites in their everyday lives truly was ridiculous: they act 
irrationally and childishly, constantly running this way and that, pursuing a thousand different projects without a single, overarching aim. They aspire to become great lords, commanding whole populations, when they are unable even to command themselves. They desire children, but then send them far away as soon as they are old enough. They chase wealth, but once they have it they either spend it foolishly or hide it away, thereby rendering it useless. Each day they are thwarted by their own vices, which they never try to correct. How could one not laugh at such ridiculousness? Hippocrates eventually comes around to this point of view, attributing Democritus' laughter not to madness but rather to his having the wisdom to see things as they truly are. Cusset rejects this assessment, though. What is truly at the origin of Democritus' laughter, he thinks, is "one of the greatest passions of philosophy," viz., contempt for ordinary people and their everyday affairs. ${ }^{6}$ The attitude of Democritus, and of philosophy generally, stems from "a slight displacement" whereby the philosopher ceases to participate directly and straightforwardly in human affairs, setting up instead a distance of reflection from which everyday life comes to appear ridiculous. ${ }^{7}$

In one of his most popular sketches, titled "Où courent-ils?" ("Where are they running?"), Raymond Devos describes a scene very similar to the one that provoked Democritus' contemptuous laughter. He begins by telling his audience that he has just returned from a strange city where everybody runs. (As in most of Devos's work, the humor consists in an extended play on words, in this case on the various idiomatic uses of the verbs courir and marcher.) When Devos asks one of the city's residents why all these people constantly run around like fools, he is told that it is because they are indeed fools. "But what is it that makes all these fools run?" asks Devos. The answer: "Everything. 
There are some who are attending to the most pressing matters [courent au plus pressé]. This one is running for glory. That one is on the road to ruin [court à sa perte]." "But why do they run so fast?" asks Devos. "To save time."

These strange people who run this way and that not really knowing what they are doing are Abderites, and their conduct makes us laugh. But the laughter provoked by Devos is importantly different from Democritus' laughter. The key to understanding the difference appears near the beginning of Devos's sketch: "When I entered the city I walked normally. But when I saw that everyone was running, I started running like everyone else, for no reason." ${ }^{9}$ Unlike Democritus, Devos situates himself among the people whose conduct appears so strange, allowing himself to be taken up into the general movement of foolishness that he describes. Our laughter is not the laughter of ridicule or mockery; instead, what makes us laugh is the fact that Devos "does not stop running while being surprised that everyone runs. ${ }^{, 10}$ All of us, Devos shows us, are Abderites, throwing ourselves into a thousand projects that, from a slightly displaced point of view, appear at least a little bit silly. But the fact that our projects are not quite as serious as we typically take them to be, that we cannot establish their genuine value on the basis of any higher truth or rationally compelling end, does not entail that they are ultimately meaningless. The laughter of Democritus, Cusset suggests, is essentially nihilist in that it is founded on a perception of everyday human affairs as amounting to nothing. The laughter provoked by Devos, on the other hand, has its source in the completion of this nihilist vision, reducing nihilism itself to nothing: it's true, our everyday affairs do not really have the weighty seriousness we typically attribute to them, 
but this fact itself need not be experienced as weighty. ${ }^{11}$ The laughter that stems from this realization is the laughter proper to humor.

\section{Epoché and the Exemption from Sense}

In his paper "Penser, S'étonner, S'éclater: Théâtre Clownesque et Étonnement Philosophique," Cusset characterizes the humorous sensibility as a kind of epoché in the phenomenological sense of the term. The humorist is able to "provisionally bracket the natural attitude of consciousness, with its naïve belief in the objective existence of what appears to it," including the kinds of social norms and practices that we take for granted in our everyday lives. ${ }^{12}$ The slight displacement that the humorist effects in our perspectives helps to make manifest the humorousness of these norms and practices. This displacement is unlike the one effected by Democritus, who situates himself outside, or more precisely above, the sphere of everyday human concerns. In the presentation of humor, both the humorist and the audience continue to situate themselves within the everyday social world, but in such a way that its taken-for-granted character is suspended. The principle of humor, Cusset thinks, consists precisely in this "sincere participation but without deep adherence." ${ }^{13}$ We laugh because it is our own world that we come to perceive differently, as less weighty.

There are good reasons, beyond the ones Cusset suggests, for thinking of the humorous sensibility as a kind of epoché. First, the world that becomes manifest under the epoché is not some other, truer world; it is exactly the same world that is given within the natural attitude. The only alteration that the epoché introduces into our experience is the suspension of our natural-attitude orientation toward the everyday world as something that is unproblematically, objectively there, independent of the cognitive acts in which it 
is given. This suspension enables us to focus our attention on the manifold ways in which the world is given to consciousness. And this, in turn, helps to restore our sense of wonder at the world. By "loosening the intentional threads that connect us to the world," the epoché "reveals the world as strange and paradoxical." "14 This is exactly what happens in humor: by loosening — but not outright breaking — the ties that connect us to our everyday projects and to their obvious, taken-for-granted importance, the humorist presents them in an ever so slightly altered light, provoking our wonder and thus our laughter.

What I want to argue, though, is that we can also profitably understand the humorous sensibility in terms of what Jean-Luc Nancy, borrowing from Roland Barthes, has called the exemption from sense. Doing so, I believe, retains the benefits of understanding it as a kind of epoché, but it also helps bring to light aspects of the humorous sensibility that are especially relevant for our thinking about ethical experience.

Roland Barthes introduces the idea of the exemption from sense in his book Empire of Signs, which is devoted to the semiology of Japanese culture. He approaches the idea by means of an examination of bunraku puppet theater, and specifically of the means it uses to present the sense of the action it depicts. What makes bunraku so different from much of Western theater, according to Barthes, is the fact that it makes no effort to conceal the artifices of its presentation. Each of the puppets is controlled by three different puppeteers, all of whom are fully visible to the audience. And off to the right of the stage, again fully visible, is the chanter, who voices each of the characters and provides the narration. Also visible is the script from which the chanter reads; it is placed 
on a lectern directly in front of him. The effect of all this is to present meaning as a surface phenomenon, spread out across all the different signifying elements that are visible on the stage. The meaning of the play, according to Barthes, is given in a flash that illuminates nothing but its own taking place. ${ }^{15}$ In Western theater, by contrast, the artifices of manifestation - the machinery, the script, the lighting sources, etc. - are typically concealed from the audience. The signifying apparatus is effaced in favor of the signified. This produces an effect of transcendence: the meaning of the play is not given as a fleeting surface event, but rather as gathered together and anchored outside the space of the performance in an origin that is supposed to be "unique [and] indivisible."16

In his book Dis-Enclosure: The Deconstruction of Christianity, Jean-Luc Nancy builds on this point, suggesting that we locate this unique and indivisible origin of sense in the vouloir dire-literally the willing to say—of the signifying subject. To remain with the example of the theater, we could say that the various signifying elements - the actors' words, gestures and costumes, the lighting, the scenery, etc.- have their true meaning gathered together and anchored in the playwright's meaning-bestowing intention. Sense, in this case, would be a "self-instituting projection of the will," an externalization of a deep and concealed interiority. ${ }^{17}$

This understanding of sense in terms of vouloir-dire strongly suggests three comportments toward sense that will help to clarify the meaning of the expression “exemption from sense." First, it suggests an orientation toward a kind of sense that is given to us in the form of an injunction: "to make sense, to produce or recognize its instance and form - would be first and foremost an imperative. (It can be shown to be the essence of the Kantian imperative.)" ${ }^{\text {18 }}$ Nancy does not flesh out his argument here, but 
the basic idea seems clear. For Kant, moral sense cannot be read off the surface of the empirically given world. We cannot discover what ought to be the case, in other words, merely by observing what is the case. Central to Kant's transcendental idealism, rather, is the idea that moral sense has its origin elsewhere, in the legislative faculty of pure practical reason. As rational beings, we cannot help but intend moral sense in accordance with the moral law, even when doing so works to our disadvantage. Because moral sense is never fully realized in the empirically given world, it is present to us as an ought-to-be, and thus as an injunction. Second, and closely related to this, is the comportment toward moral sense as a unique sense. ${ }^{19}$ Again, we can understand this point with reference to Kant, for whom there is one and only one source of genuine moral sense: the categorical imperative. Of course Kant gives different formulations of the imperative, but he insists that these are "at bottom only so many formulae of the very same law" and that each contains all the others. ${ }^{20}$ Finally, the understanding of sense in terms of vouloir-dire suggests a conception of the practical subject as master of moral sense. According to Nancy, "the wanting-to-say commanded by sense always consists, in sum, in a wantingto-have-said ("I have said" is the word of the master). ${ }^{, 21}$ Because moral sense has its origin in our own faculty of pure practical reason, we should never be in any sincere doubt about what we are morally required to do. Kant expresses this idea of moral mastery especially clearly when he writes that "the most common understanding" can always determine what is morally required "quite easily and without hesitation." 22 As sources of the moral law, each of us "knows very well how to distinguish in every case that comes up what is good and what is evil, what is in conformity with duty or contrary to duty.....23 
The laughter of Democritus stems from this imperative of mastery. He sets himself at a distance from the everyday lives of his fellow Abderites, determining the sense of their behavior unilaterally and with perfect self-confidence. The Abderites themselves, he concludes, go about their day-to-day business without understanding the true sense of what they are doing or of what is most worth doing. Democritus takes himself to be the master of the sense that the Abderites lack. Sitting comfortably in the judge's seat, he recognizes "quite easily and without hesitation" the many ways in which their behavior is objectively ridiculous.

The exemption from sense, by contrast, would consist in the lifting of this obligation to position ourselves as masters of a uniquely authoritative sense. It is a suspension, in other words, of the imperative to get a distance from naïve, everyday experience and to discover the true, self-present meaning that would provide its measure. Instead of trying to issue definitive verdicts on the sense of the situations we find ourselves in, we are called upon to find "a renewed, refined, and ever more finely honed word," one that is "always closer to its birth than its closure, always more governed by its saying than by its said, by its reserve more than by its last word. ${ }^{24}$ In the exemption from sense, we find ourselves oriented toward sense as shared, as something that emerges most originarily right at the level of our openness to each other: "what makes sense," in the most literal sense of the idiom, "is one person speaking to another." ${ }^{25}$ This slight displacement in perspective gives others to appear not primarily as particular instances of significant kinds — as uneducated, as men or women, as Abderites, etc.—-but rather as singular, and thus as wonderful. ${ }^{26}$ It is this kind of experience, Nancy argues, that is captured in the common saying "people are strange:" the other is given most originarily 
as “incomparable or inassimilable, not because it is simply 'other' but because it is an origin and a touch of meaning.... You are absolutely strange because the world begins its turn with you. ${ }^{27}$

The laughter of Devos, I want to argue, arises from the lifting of the imperative of sense. Instead of distancing himself from the everyday experience of the Abderites, setting himself up as their judge, Devos runs right along with them. Just as in the case of bunraku puppet theater, we see the sense of their lives lighting up at the surface, right at the level of their exposure to each other. Nobody, including Devos, is the master of this sense. The sensibility that arises from the suspension of this imperative is very much like what Cusset characterized as the completion of the nihilist vision: the world comes to appear as lacking the weighty seriousness of foundational sense, but this lack itself is not experienced as weighty.

\section{The Humorous Sensibility and Contempt}

As these references to Kantian imperatives and to the singularity of the other suggest, the humorous sensibility, thematized in terms of the exemption from sense, is in some respects also an ethical sensibility. In what follows, I would like to focus specifically on the way in which the humorous sensibility is entirely incompatible with the experience of others as contemptible. To show how this is the case, it will be necessary to describe as precisely as possible what it means to hold someone in contempt. I will begin, then, by isolating four features that psychologists of emotion and philosophers working on the ethics of contempt have typically considered to be essential to the phenomenon. 
First, contempt tends to manifest itself in avoidance of the contemned. Among psychologists of emotion, Agneta Fischer and Ira Roseman have been the most influential advocates for this view, arguing that contempt is best understood as belonging to what they call the exclusion family of emotions. ${ }^{28}$ Instead of confronting perceived wrongdoers and calling them to account for their bad behavior, as we do in anger, we simply exclude them from our social networks. Philosopher Kate Abramson agrees with this characterization, arguing largely on the basis of our commonsense understanding of what contempt means: if "I tell you that I'm contemptuous of Joe but spend a good deal of time with him, you would likely begin to wonder whether I really find him contemptible. ${ }^{29}$ And finally, Thomas E. Hill clearly has this idea of contempt as avoidance in mind when he characterizes the phenomenon as "a deep dismissal, a denial of the prospect of reconciliation, a signal that the conversation is over." ${ }^{, 30}$

Second, contempt is a hierarchizing attitude: when we contemn someone, we regard her as low in comparison to ourselves. From the very beginning, psychologists of emotion who have written on contempt have been nearly unanimous on this point. In his 1977 book Human Emotions, for example, Carroll Izard described contempt as "the feeling of being superior, of being better than someone, some group or some thing," adding that it might also be "the feeling that one's family, one's culture, or one's society is superior to and better than someone else's." ${ }^{31}$ And Hugh Wagner included the "feeling of superiority over another person (or of the other's inferiority)" as the second element in his three-part working definition of contempt. ${ }^{32}$ In her groundbreaking paper "Contempt as a Moral Attitude," Michelle Mason expands on this idea, arguing that contempt is best understood as "presenting its object as low in the sense of ranking low in worth as a 
person in virtue of falling short of some legitimate interpersonal ideal of the person...., Likewise, Macalester Bell characterizes contempt as "a demoting emotion that presents its target as having a comparatively low status." 34 And Kate Abramson describes contempt as being directed toward "persons held in low esteem simply as persons.",35 Third, contempt is a globalizing emotion. This is closely related to the previous point: when we judge the target of our contempt to be low, what we have in mind is always a person or group of persons taken as a whole, and never some particular acts that have been attributed to the person or group or some particular aspect of their character. This point is given special emphasis by Michelle Mason and Macalester Bell. As Mason notes, the global focus of contempt is strongly suggested by the ways we talk about it in everyday English: “one typically holds in contempt, regards with contempt, or expresses contempt for , where what fills the blanks are particular persons or groups of persons." ${ }^{36}$ It would be very unusual to say that we hold a person's having embezzled from his employer or his having committed adultery in contempt. It is of course perfectly natural to say that we resent the person's having embezzled or his having committed adultery, but that is something different from contemning them. What we contemn are the authors of these acts, the embezzler or the adulterer as whole persons. Macalester Bell expresses the same point when she writes that "contempt is a response to perceived badbeing whereas hard feelings like resentment and guilt are responses to perceived wrongdoing., ${ }^{, 37}$

Finally, contempt is a third-personal attitude. This point is emphasized especially clearly by Stephen Darwall, who argues that when we contemn someone, we characterize her, reducing her to a contemptible quality that defines who she is essentially. ${ }^{38}$ When we 
blame someone, by contrast, we engage with her second-personally: we regard her as an equal member of the moral community, willing and able to make herself answerable to the charges of moral wrongdoing we bring against her. Blame, in other words, is a form of address directed to the one who has wronged us, or who we believe has wronged us. Like all reactive attitudes, blame comes with an implicit RSVP: we give the other person the opportunity to respond to our address, perhaps to apologize for her having wronged us, but also perhaps to provide an excuse or to present us with an argument that what she had done was not morally wrong at all. ${ }^{39}$ Contempt, on the other hand, is a judgment about the contemned; it does not come with an implicit RSVP. If it is an address at all, it is addressed to "other cognoscenti who have the same superior view of the contemned's contemptible character." ${ }^{40}$

There can be little doubt that Democritus's laughter expresses contempt, in this sense of the term, for the Abderites. As we have seen, his relation to them is entirely third personal: his laughter is not addressed to them, inviting them to defend or to justify their ways of life to him. Rather, his laughter expresses a characterization of the Abderites as ridiculous. Insofar as his laughter constitutes an address at all, the addressee is Hippocrates, whom Democritus regards as his equal and thus as worthy of secondpersonal engagement. The Abderites themselves, from Democritus's point of view, are clearly beneath him. And this judgment is intended to be global in scope: its object is not some particular, isolated quality, such as the Abderites' weakness in money management or their failure to successfully subordinate their various projects to one overarching end. What is ridiculous, rather, is the Abderites taken as whole persons and as a group. 
The laughter that stems from the humorous sensibility is very different in all of these respects. In his sketch "Où courent-ils?" Raymond Devos does not characterize the Abderites, reducing them to qualities that are taken to be definitive of them. Neither does he look down on them, judging them to have fallen "short of some legitimate interpersonal ideal of the person." Instead, he runs right along with them, expressing wonder at the lightness of the meaning that happens between them. This wonder, and not our sense of our own superiority, is what elicits our laughter. As we have seen, humorous sense is a phenomenon of the surface: it arises nowhere else than at the level of our being-together. In the humorous sensibility, then, others are given, in Nancy's terms, as singular, as incomparable and inassimilable origins of meaning. This sensibility is simply incompatible with the attitude of contempt.

\section{Normative Implications of the Humorous Sensibility}

In this final section I would like to develop some of the implications of the humorous sensibility, understood in terms of the exemption from sense, for our thinking about the ethics of contempt. Specifically, I want to argue that this account supports a broadly, but not entirely, Kantian view of the moral impermissibility of treating others with contempt. In The Metaphysics of Morals, Kant argues that "to be contemptuous of others (contemnere), that is, to deny them the respect owed to human beings in general, is in every case contrary to duty. ${ }^{, 41}$ This position may seem quintessentially Kantian, but in fact it is entirely in keeping with a broad consensus on the question of contempt that had gone back at least a century and a half. Thomas Hobbes, for example, argued in On the Citizen that the natural law obligated us to refrain from showing "hatred or contempt of

another by deeds, words, facial expressions, or laughter." ${ }^{, 42}$ And in his Treatise on Ethics, 
Nicolas Malebranche insisted that contemning others was not only wrong, but "the greatest of wrongs." ${ }^{, 43}$ What is unique to Kant's view of the ethics of contempt is the combination of this view with a strong commitment to the claim that some people truly are contemptible. In the Lectures on Ethics, for example, he argues that we dispose of our humanity, and thus render ourselves contemptible, when we sell parts of our own bodies or allow ourselves to be used for the sexual pleasure of others. In performing such acts, we renounce our own subjectivity, reducing ourselves to the level of mere things. ${ }^{44}$ In practicing other vices, such as drunkenness and gluttony, we render ourselves contemptible by reducing ourselves to the level of the non-rational animals. ${ }^{45}$ And in the Doctrine of Virtue, Kant argues that the vices of lying, avarice, and servility are contrary to inner freedom and human dignity; to adopt them is to "throw oneself away and make oneself an object of contempt. ${ }^{\text {"46 }}$ This commitment gives rise to a very difficult problem for Kant's view: if the moral law, which has its source in the legislative faculty of pure practical reason, shows some persons to be objectively contemptible, then how can that same law forbid us from contemning them? What makes this problem even more difficult is the fact that the command not to contemn is categorical, not hypothetical. This means that the reason for the prohibition on contemning others cannot be prudential. It seems on Kant's account, then, as if pure practical reason commands us unconditionally to disregard the moral sense that it itself legislates. How can we make sense of this?

I believe that the modified version of Cusset's account of the humorous sensibility developed above gives us some valuable resources for resolving this tension in Kant's position, and more importantly for clarifying our own thinking about the ethics of contempt ${ }^{47}$ For Kant, as well as for the vast majority of writers on the subject, contempt 
is a globalizing judgment. This is clear from the passages cited above: by practicing certain vices we throw ourselves away or reduce ourselves to the level of mere things. It is also clear in his definition of contempt as "judging something to be worthless." ${ }^{48}$ From within a moral sensibility shaped by what Nancy characterized as the imperative of unique, authoritative sense, these kinds of globalizing judgments may seem perfectly apt. But the humorous sensibility, characterized by an exemption from the imperative of sense, gives us a vivid example of how globalizing moral judgments fail to capture whole persons. By a slight displacement of perspective, we can come to recognize in even the most contemptible people a difficult-to-articulate something that is passed over in our moralizing judgments. This excessive something is present to us in the experience of wonder that humor can elicit: others are given not primarily as instances of moral kindsas liars, manipulators, gluttons, etc. - but as singular origins of the meaning of the world. And as we have seen, this experience of others is simply incompatible with an attitude of contempt.

Do we have an obligation, then, to cultivate a humorous sensibility, comporting ourselves toward others in something like the way Devos comports himself toward the Abderites? Should we treat the open-ended, excessive, surface dimension of sense that this comportment reveals as overriding the kind of fixed, authoritative, and unique sense that is given from the Democritean point of view, in something like the way the moral law in Kant always overrides prudential considerations? The answer to these questions, I believe, is no. Phenomenologically, the humorous sensibility is not given as necessarily overriding all other sensibilities. It is given, rather, in the way that Bernard Williams thinks the sense of obligation is actually given in our real, everyday experience: simply as 
one sensibility among others. ${ }^{49}$ Moreover, there are certainly cases in which the humorous sensibility is not called for. Although the humorous sensibility is incompatible with the third-person perspective that is characteristic of contempt, it is not itself a second-person perspective. It is not, in other words, a sensibility in which others are given as equal members of a moral community, answerable to us in cases where we feel they have wronged us, but also authorized to hold us accountable for our actions. But surely this kind of comportment toward others, and toward ourselves, is sometimes more appropriate than the attitude of "sincere participation but without deep adherence" that characterizes the humorous sensibility.

If this is correct, then we can agree with Kant that our attitudes toward very bad people are irreducibly conflicted, that we have strong reasons to treat them with contempt and that we also have strong reasons not to. But I do not believe we should go quite as far as Kant in concluding that the reasons not to contemn necessarily override the reasons to contemn. If a financial advisor has tricked our elderly and vulnerable grandparents out of their life savings, for example, we cannot know "quite easily and without hesitation" that we would wrong him by forming a global judgment of him as low and by forgoing second-personal relations with him. Of course this financial advisor, like everyone else, is more than his bad character; he is also, as Nancy says, a singular, inassimilable origin of the world. But we cannot rule out in advance the possibility that the wrongdoer's singularity may not be the most important moral consideration, especially for those who have been adversely affected by his bad acts. All the same, we can be sure that it is a consideration that always matters at least to some extent. And when we situate ourselves, like Democritus, firmly in the judge's seat, we are very likely to lose sight of this. 
Occupying this position, we run a very great risk of committing ourselves to strongly one-sided, self-aggrandizing, and unjust moral judgments and of closing ourselves off from the possibility of modifying those judgments in response to new evidence. Even in cases where our judgments of contempt are indeed appropriate, all things considered, we should still be careful to resist the temptation to reduce the wrongdoer completely to his bad character traits. The humorous sensibility, I believe, helps us to do exactly that: by effecting an exemption from the imperative of unique, authoritative sense, and by bringing into relief the singularity and incomparability of our fellows, it helps us to resist our dangerous tendency to get too comfortable in our position as masters of moral sense, opening us to the very real possibility that we have treated the other unjustly. 
${ }^{1}$ Aristotle, Poetics in The Complete Works of Aristotle, Volume II, ed. Jonathan Barnes (Princeton: Princeton University Press, 1984), 1149a 33-35.

${ }^{2}$ Quintilian, The Institutio Oratoria of Quintilian, with an English Translation, trans. H.E. Butler (Cambridge: Harvard University Press, 1921), 443.

${ }^{3}$ Thomas Hobbes, The Elements of Law, Natural and Politic, ed. Ferdinand Tönnies (New York: Routledge, 2013), 42.

${ }^{4}$ Charles Baudelaire, "Of the Essence of Laughter, and generally of the Comic in the Plastic Arts" in Baudelaire: Selected Writings on Art and Artists, trans. P.E. Charvet (Cambridge: Cambridge University Press, 1972), 146.

${ }^{5}$ Thomas Hobbes, On the Citizen, ed. Richard Tuck and Michael Silverthorne (Cambridge: Cambridge University Press, 1998), 49. Hereafter OC; Samuel Pufendorf, On the Duty of Man and Citizen, ed. James Tully, trans. Michael Silverthorne (Cambridge: Cambridge University Press, 1991), 63.

${ }^{6}$ Yves Cusset, Rire: Tractatus philo-comicus (Paris: Flammarion, 2016), 60. Hereafter Rire. All translations from this work are my own.

${ }^{7}$ Ibid., 55.

${ }^{8}$ Ibid., 57.

${ }^{9}$ Ibid.

${ }^{10}$ Ibid., 59.

${ }^{11}$ Ibid., 225.

${ }^{12}$ Yves Cusset, "Penser, S'étonner, S'éclater: Théâtre Clownesque et Étonnement Philosophique," Vie Sociale 2 (2010): 30.

${ }^{13}$ Cusset, Rire, 62.

${ }^{14}$ Maurice Merleau-Ponty, Phenomenology of Perception, trans. Donald A. Landes (London: Routledge, 2012), lxxvii.

${ }^{15}$ Roland Barthes, Empire of Signs, trans. Richard Howard (New York: Hill and Wang, 1982), 83.

${ }^{16}$ Ibid., 59.

${ }^{17}$ Jean-Luc Nancy, Dis-Enclosure: The Deconstruction of Christianity, trans. Bettina Bergo, Gabriel Malenfant, and Michael B. Smith (New York: Fordham University Press, 2008), 124. Hereafter DisEnclosure.

${ }^{18}$ Ibid., 125.

${ }^{19}$ Ibid., 126.

${ }^{20}$ Immanuel Kant, Groundwork of the Metaphysics of Morals in Immanuel Kant, Practical Philosophy, The Cambridge Edition of the Works of Immanuel Kant, trans. and ed., Mary J. Gregor (Cambridge: Cambridge University Press, 1996), 85 [4:436]. Page numbers in brackets refer to those of the Akademie Edition. Hereafter GMM. 
${ }^{21}$ Nancy, Dis-Enclosure, 126.

${ }^{22}$ Immanuel Kant, Critique of Practical Reason in Immanuel Kant, Practical Philosophy, The Cambridge Edition of the Works of Immanuel Kant, trans. and ed., Mary J. Gregor (Cambridge: Cambridge University Press, 1996), 169 [5:36]. Page numbers in brackets refer to those of the Akademie Edition.

${ }^{23}$ Kant, GMM, 58 [4:404].

${ }^{24}$ Nancy, Dis-Enclosure, 126.

${ }^{25}$ Ibid., 128. Italics omitted.

${ }^{26}$ Ted Cohen, focusing specifically on jokes, makes a similar point. The most important function of jokes, he argues, is not to establish a distance from others or to express the truth about them, but rather to help create a greater intimacy with them: "That we [laugh] together is the satisfaction of a deep human longing, the realization of a desperate hope. It is the hope that we are enough like one another to sense one another, to be able to live together." Ted Cohen, Jokes: Philosophical Thoughts on Joking Matters (Chicago:

University of Chicago Press, 1999), 29.

${ }^{27}$ Jean-Luc Nancy, Being Singular Plural, trans. Robert D. Richardson and Anne E. O’Byrne (Stanford: Stanford University Press, 2000), 6.

${ }^{28}$ Agneta H. Fischer and Ira J. Roseman, "Beat Them or Ban Them: The Characteristics and Social Functions of Anger and Contempt" Journal of Personality and Social Psychology 99, no. 1 (2007): 103-

104. Cf. Diane M. Mackie, Thierry Devos, and Eliot R. Smith, "Intergroup Emotions: Explaining Offensive Action Tendencies in an Intergroup Context" Journal of Personality and Social Psychology 79, no. 4 (2000): 612: "Whereas anger mediated intended action against the out-group, the experience of contempt was associated with the desire to move away from the out-group."

${ }^{29}$ Kate Abramson, "A Sentimentalist's Defense of Contempt, Shame, and Disdain" in Peter Goldie, ed., The Oxford Handbook of Philosophy of Emotion (Oxford: Oxford University Press, 2009), 202. Hereafter SD. Cf. Robert C. Solomon, The Passions: Emotions and the Meaning of Life (Indianapolis: Hackett Publishing Company, 1993), 234. Hereafter The Passions.

${ }^{30}$ Thomas E. Hill, Respect, Pluralism, and Justice: Kantian Perspectives (Oxford: Oxford University Press, 2000), 60 .

${ }^{31}$ Carroll E. Izard, Human Emotions (New York: Plenum, 1977), 339.

${ }^{32}$ Hugh L. Wagner, "The Accessibility of the Term 'Contempt' and the Meaning of the Unilateral Lip Curl” Cognition and Emotion 14, no. 5 (2000): 695.

${ }^{33}$ Michelle Mason, “Contempt as a Moral Attitude” Ethics 113, no. 2 (2003): 241. Hereafter CMA.

${ }^{34}$ Macalaster Bell, Hard Feelings: The Moral Psychology of Contempt (Oxford: Oxford University Press, 2013), 128. Italics omitted. Hereafter Hard Feelings.

${ }^{35}$ Abramson, SD, 205. Cf. Solomon, The Passions, 234; Richard B. Brandt, "Moral Valuation," Ethics 56, no. 2 (1946): 114.

${ }^{36}$ Mason, CMA, 246.

${ }^{37}$ Bell, HF, 39 . 
${ }^{38}$ Stephen Darwall, "Contempt as an Other-Characterizing, 'Hierarchizing' Attitude" in Michelle Mason, ed., The Moral Psychology of Contempt (Lanham, MD: Rowman \& Littlefield, 2018), 229. Hereafter COCHA.

${ }^{39}$ Stephen Darwall, The Second-Person Standpoint: Morality, Respect and Accountability (Cambridge: Harvard University Press, 2006), 40.

${ }^{40}$ Darwall, COCHA, 229.

${ }^{41}$ Immanuel Kant, The Metaphysics of Morals in Immanuel Kant, Practical Philosophy, The Cambridge Edition of the Works of Immanuel Kant, trans. and ed., Mary J. Gregor (Cambridge: Cambridge University Press, 1996), 579 [6:463]. Page numbers in brackets refer to those of the Akademie Edition.

${ }^{42}$ Hobbes, OC 49. Italics omitted.

${ }^{43}$ Nicolas Malebranche, Treatise on Ethics, trans. Craig Walton (Dordrecht: Kluwer, 1992), 173. Translation modified.

${ }^{44}$ Immanuel Kant, Lectures on Ethics, The Cambridge Edition of the Works of Immanuel Kant, ed. Peter Heath and J.B. Schneewind, trans. Peter Heath (Cambridge: Cambridge University Press, 1997), 157 [27:386]. Hereafter LE. Page numbers in brackets refer to those of the Akademie Edition.

${ }^{45}$ Ibid., 420 [27:692-93].

${ }^{46}$ Kant, MM, 545 [6:420].

${ }^{47}$ Kant, of course, has his own account of humor, which he develops very briefly in Section 54 of his Critique of the Power of Judgment. Kant's account is an example of what is now called Incongruity Theory, according to which laughter is produced by the violation of our expectations: "In everything that is to provoke a lively, uproarious laughter, there must be something nonsensical (in which, therefore, the understanding in itself can take no satisfaction). Laughter is an affect resulting from the sudden transformation of a heightened expectation into nothing." Immanuel Kant, Critique of the Power of Judgment, The Cambridge Edition of the Works of Immanuel Kant, ed. Paul Guyer, trans. Paul Guyer and Eric Matthews (Cambridge: Cambridge University Press, 2000), 209 [5:332]. Page numbers in brackets refer to those of the Akademie Edition. Kant has very little to say about the implications of his account of humor for ethics. For an argument that attempts to spell out some of those implications, see Annie Hounsokou, "'Exposing the Rogue in Us': An Exploration of Laughter in the Critique of Judgment," Epoché: A Journal for the History of Philosophy, Vol. 16, no. 2 (2002): 317-36.

${ }^{48}$ Ibid., 579 [6:462].

${ }^{49}$ Bernard Williams, "Morality, the Peculiar Institution" in Ethics and the Limits of Philosophy (Cambridge: Harvard University Press, 1985), 174. 


\section{Works Cited}

Abramson, Kate. "A Sentimentalist's Defense of Contempt, Shame, and Disdain.” In Peter Goldie, ed., The Oxford Handbook of Philosophy of Emotion. Oxford: Oxford University Press, 2009.

Aristotle. Poetics. In The Complete Works of Aristotle, Volume II, ed. Jonathan Barnes. Princeton: Princeton University Press, 1984.

Barthes, Roland. Empire of Signs. Translated by Richard Howard. New York: Hill and Wang, 1982.

Baudelaire, Charles. "Of the Essence of Laughter, and generally of the Comic in the Plastic Arts." In Baudelaire: Selected Writings on Art and Artists. Translated by. P.E. Charvet. Cambridge: Cambridge University Press, 1972.

Bell, Macalester. Hard Feelings: The Moral Psychology of Contempt. Oxford: Oxford University Press, 2013.

Brandt, Richard B. “Moral Valuation.” Ethics 56, no. 2 (1946): 106-121.

Cohen, Ted. Jokes: Philosophical Thoughts on Joking Matters. Chicago: University of Chicago Press, 1999.

Cusset, Yves. Rire: Tractatus philo-comicus. Paris: Flammarion, 2016.

"Penser, S'étonner, S'éclater: Théâtre Clownesque et Étonnement Philosophique." Vie Sociale 2 (2010): 27-37.

Darwall, Stephen. "Contempt as an Other-Characterizing, 'Hierarchizing' Attitude." In Michelle Mason, ed., The Moral Psychology of Contempt. Lanham, MD: Rowman \& Littlefield, 2018.

The Second-Person Standpoint: Morality, Respect and Accountability. Cambridge: Harvard University Press, 2006.

Fischer, Agneta H. and Ira J. Roseman. "Beat Them or Ban Them: The Characteristics and Social Functions of Anger and Contempt." Journal of Personality and Social Psychology 99, no. 1 (2007): 103-115.

Hill, Thomas E. Respect, Pluralism, and Justice: Kantian Perspectives. Oxford: Oxford University Press, 2000 .

Hobbes, Thomas. The Elements of Law, Natural and Politic. Edited by Ferdinand Tönnies. New York: Routledge, 2013.

. On the Citizen. Edited by Richard Tuck and Michael Silverthorne. Cambridge: Cambridge University Press, 1998.

Hounsokou, Annie. “'Exposing the Rogue in Us': An Exploration of Laughter in the Critique of Judgment." Epoché: A Journal for the History of Philosophy 16, no. 2 (2012): 317-336.

Izard, Carroll E. Human Emotions. New York: Plenum, 1977.

Kant, Immanuel. Critique of the Power of Judgment. In The Cambridge Edition of the Works of Immanuel Kant. Edited by Paul Guyer. Translated by Paul Guyer and Eric Matthews. Cambridge: Cambridge University Press, 2000. 
. Lectures on Ethics. In The Cambridge Edition of the Works of Immanuel Kant. Edited by

Peter Heath and J.B. Schneewind. Translated by Peter Heath. Cambridge: Cambridge University Press, 1997.

Critique of Practical Reason. In Immanuel Kant, Practical Philosophy, The Cambridge

Edition of the Works of Immanuel Kant. Translated and edited by Mary J. Gregor. Cambridge:

Cambridge University Press, 1996

Groundwork of the Metaphysics of Morals. In Immanuel Kant, Practical Philosophy, The Cambridge Edition of the Works of Immanuel Kant. Translated and edited by Mary J. Gregor. Cambridge: Cambridge University Press, 1996.

The Metaphysics of Morals. In Immanuel Kant, Practical Philosophy, The Cambridge Edition of the Works of Immanuel Kant. Translated and edited by Mary J. Gregor. Cambridge: Cambridge University Press, 1996.

Mackie, Diane M., Thierry Devos, and Eliot R. Smith. "Intergroup Emotions: Explaining Offensive Action Tendencies in an Intergroup Context." Journal of Personality and Social Psychology 79, no. 4 (2000): 602-616.

Malebranche, Nicolas. Treatise on Ethics. Translated by Craig Walton. Dordrecht: Kluwer, 1992.

Mason, Michelle. “Contempt as a Moral Attitude.” Ethics 113, no. 2 (2003): 234-272.

Merleau-Ponty, Maurice. Phenomenology of Perception. Translated by Donald A. Landes. London: Routledge, 2012.

Nancy, Jean-Luc. Dis-Enclosure: The Deconstruction of Christianity. Translated by Bettina Bergo, Gabriel Malenfant, and Michael B. Smith. New York: Fordham University Press, 2008.

Being Singular Plural. Translated by Robert D. Richardson and Anne E. O’Byrne. Stanford: Stanford University Press, 2000.

Pufendorf, Samuel. On the Duty of Man and Citizen. Edited by James Tully. Translated by Michael Silverthorne. Cambridge: Cambridge University Press, 1991.

Quintilian. The Institutio Oratoria of Quintilian, with an English Translation. Translated by H.E. Butler. Cambridge: Harvard University Press, 1921.

Solomon, Robert C. The Passions: Emotions and the Meaning of Life. Indianapolis: Hackett Publishing Company, 1993.

Wagner, Hugh L. "The Accessibility of the Term 'Contempt' and the Meaning of the Unilateral Lip Curl." Cognition and Emotion 14, no. 5 (2000): 689-710.

Williams, Bernard. "Morality, the Peculiar Institution." In Ethics and the Limits of Philosophy. Cambridge: Harvard University Press, 1985. 